\title{
Agency and Insecurity: The Socio-Economic Experiences and Trajectories of Chinese Migrant Traders in the City of Durban
}

\author{
Subashini Gordon \\ Kathryn Pillay
}

\begin{abstract}
The beginning of the millennium marked an increase in Chinese diplomatic and commercial ties with South Africa. This resulted in a 'new wave' of Chinese migration to the country, particularly to the city of Durban. These new Chinese entrepreneurs work in so called 'China Malls', created specifically for the trade of goods manufactured in China. Although Chinese migrant traders are visible in these spaces, their lives seem shrouded in secrecy. Through data obtained from a series of qualitative interviews and participant observation, this article explores the socio-economic experiences of Chinese migrant traders in the city of Durban. This study reveals that although social networks provide the impetus for creating and sustaining businesses, issues of insecurity, prejudice and language limits their ability to engage in meaningful social interaction within South Africa.
\end{abstract}

Keywords: Chinese migration; social networks, crime, prejudice, traders

\section{Introduction}

With South Africa attaining democratic status in 1994, and the establishment of diplomatic and economic relations with the People's Republic of China $(\mathrm{PRC})^{1}$, a 'new wave' of Chinese migration into the country began (Park

\footnotetext{
${ }^{1}$ In this study China is used to refer to the PRC, while Taiwan is referred to as the Republic of China (ROC).
} 
$2009)^{2}$. Bilateral trade agreements between the two states from the year 2000 onwards also provided the necessary means for Chinese commodities and people to enter the country (Accone 2006). The result of these agreements was noted in 2006 when the South African government made an announcement concerning the increasing 'wave' of Chinese people entering South Africa, with Wilhelm (2006:325) noting that 'the biggest inflow is from the new generation of migrants from mainland China'. Park (2012:6) estimates that there could be between $350000-500000$ new Chinese migrants in South Africa, however 'due to irregular migration, poor record keeping and corruption within South African government agencies' as well as illegal migration, accurate statistics are difficult to attain.

These new Chinese migrants often penetrate the commercial markets by trading in various types of goods ranging from clothing and footwear, to electronic goods and everyday household items (Kuo 2017). In recent years, the city of Durban in particular, has witnessed an increase in Chinese migrants together with their business establishments. The Chinese traders tend to set up their commercial enterprises at key trading areas where it is most convenient to trade with local, and most noticeably, foreign African migrants. Although the Chinese migrants and their business enterprises are visible on the streets of Durban's city centre, and malls are created primarily for Chinese entrepreneurs to trade Chinese made products, their lives seem shrouded in secrecy as they are mainly confined to these 'Chinese shops' ${ }^{3}$. Through data obtained from a series of qualitative interviews and participant observation, this article explores the socio-economic experiences of Chinese migrant traders in the city of

${ }^{2}$ Accone (2006:257) indicates that the Chinese in South Africa are not a homogenous group but are diverse in 'race, ethnicity, language and culture'. A firm distinction is therefore made between South African Born Chinese (SABC's) whose ancestors have shared a long and tumultuous history in South Africa (Yap \& Man, 1996) and Chinese people who have recently entered South Africa from the year 1994 onwards who have been termed 'new Chinese migrants' (Accone 2006; Park 2009; Park \& Chen, 2009). The focus of this article is on 'new Chinese migrants' and not on SABC's. Henceforth when reference is made to Chinese people it is in respect of the new Chinese migrants, unless otherwise stated.

3 'Chinese shops' are seen as 'Chinese owned shops that sell Chinese made goods for the everyday South African consumer' (Laribee 2008:355). 
Durban. In so doing, this article examines how social networks provide the impetus for creating and sustaining businesses and reveals how issues of insecurity and prejudice limits the Chinese migrant's ability to engage in meaningful social interaction within South Africa.

\section{A Brief History of Chinese Migration in South Africa}

The first Chinese migrants to South Africa, were brought to the Cape as slaves and convicts, by the Dutch East Indian Company who controlled the trading port from 1652 to 1795 (Park 2009:26). Thereafter, Chinese migrants started to arrive in South Africa in three defined time periods, which was precipitated mainly by economic 'pull' factors to South Africa. A wave of Chinese migration to South Africa and return migration was primarily due to political 'push' factors.

Laribee (2008:357) indicates that the Chinese migrated to South Africa in 'three distinct waves; three groups of immigrants whose passports may have displayed the same country's name but in actuality have come from three very different Chinas'. The first wave of Chinese immigration to South Africa began in the 1870s during the colonial period (Laribee 2008:357). Some of these Chinese immigrants are the ancestors of the local or South African born Chinese (SABC). Huynh et al. (2010:289) point out that 'the Chinese South African community of approximately 10000 is made up of 2nd, 3rd, and 4th generation South Africans whose ancestors began arriving from China in the late 1870s'. These Chinese migrants came independently to seek new opportunities in the gam saan or 'Gold Mountain' as gold mines had been discovered in Johannesburg in the 1800s (Laribee 2008; Yap \& Man 1996). These Chinese migrants originated from two areas, about $400 \mathrm{~km}$ apart, in the Kwangtung (Guangdong) province of south China and could be ethnically distinguished as Cantonese and Moiyeanese (or Hakka). These migrants 'spoke different dialects, practiced different customs and their relations both in their home province and abroad were marked by traditional animosity ... despite the fact that outsiders saw them all simply as "Chinese" (Yap \& Man 1996:3233). Accone (2006:261) who describes the relationship between the two groups of Chinese as bitter also states that they settled in different regions to avoid each other, indicating that the 'Cantonese settled largely in Johannesburg, Pretoria and the wider Witwatersrand area while the Moiyeanese made the coastal towns their home - principally Port Elizabeth and East London, with 
smaller groupings in Cape Town and Durban'. During the 1900s, however, ethnic differences between the two groups became blurred (Yap and Man, 1996:35). According to census data there were a total of 413 Chinese living in South Africa in 1891. By 1904 this number increased to 2 556, however this number remained small in relation to the South African population (Park 2009; Song 1993).

The migration of Chinese people to South Africa however came to a halt as racialised discriminatory and tyrannical laws promulgated by the union government (1910-1948) and thereafter the apartheid government (19481994) negatively affected 'non-White' groups in South Africa. South Africa was built on a racialised ideology of White supremacy where false 'race' science was used to justify oppressive political, economic and social treatment of 'non-White' people. The South African population was divided and racially classified into four main groups, 'Black', 'Coloured', 'India/Asian/Asiatic' and 'White', who were forced to live in separate localities as a result of the Group Areas Act of 1950. In addition, resources were unequally and unfairly distributed amongst 'race' groups; with the 'White' population receiving the greatest proportion of the resources which meant that other groups were economically oppressed and became destitute under these laws. Chinese people, as well as people of Indian descent were classified as 'Asian', thus any discriminatory law aimed at 'Indians' also affected Chinese people. Although the Chinese formed a small population, they were treated harshly based on their 'race' (Christopher 2002; Seekings 2008). The Immigrants Regulation Amendment Act 43 of 1953, which was directed at the immigration of 'Indians' into the country also affected Chinese migration into South Africa (Horrell 1954). Due to the challenges posed by this law, only a small number of isolated cases of Chinese entering South Africa was noted, these included, Chinese brides who came between 1949-1953, Chinese chefs who had temporary permits and illegal immigrants who were eager to join their family in South Africa (Park 2009; Song 1993).

The second wave of Chinese migrants who came to South Africa during the 1970s and 1980s, originated from Taiwan (Huynh et al. 2010). The South African apartheid government that was under sanctions, and Taiwan, which was an isolated country at the time fostered friendly trade relationships. Taiwanese migrants consisted of mainly industrialists looking to invest and set up manufacturing enterprises in South Africa. The South African government also offered the Taiwanese generous incentive schemes. These incentives 
included 'relocation costs, subsidized wages for seven years and subsidized rent for ten years, cheap transport of goods to urban areas, and housing loans, and favourable exchange rates to encourage the immigration of investors and their families from the ROC as well as Hong Kong, which was still a British protectorate at the time' (Huynh et al. 2010) ${ }^{4}$. The laws that prevented Asian immigration to South Africa were thus waived to allow Taiwanese industrialists to enter. In 1988 around 2500 Taiwanese entered South Africa, and by 1992 the number of Taiwanese in South Africa grew rapidly to 30011. The Taiwanese industrialists established nearly 150 factories especially in the remote parts of South Africa and created more then 40000 jobs; they also invested R1 billion in capital (Huynh et al. 2010).

When South Africa became a democracy in 1994, the first democratically elected government, severed ties with Taiwan in favour of the PRC in January 1998. Although Taiwan had assisted South Africa during the transitional period from apartheid to democracy through various investments, development plans, job creation initiatives, loans and donations, in comparison to the PRC, China was adamant on its 'One China' policy which forced countries to choose between the PRC and the ROC (Geldenhuys 1995). South Africa's acceptance of the 'one China' concept 'opened way for full diplomatic interaction with China, while maintaining economic links with Taiwan' (Guliwe \& Mkhonto 2009:302). In the late 1990s to the early 2000s, most Taiwanese left South Africa. Their decision to leave was based on the 'termination of their subsidies, South Africa's official recognition of the People's Republic of China (PRC), difficulties with South Africa's labour regulations, and stiff competition from the entry of cheap imports brought in directly from China' (Park \& Chen 2009:28). Other issues that the Taiwanese found challenging were the crime and security problems within the country as well as the increase of new migrants in small towns (Park \& Chen 2009:28). In addition to this, the political and economic climate at the time, with an increase in the interest rate and the depreciation of the South African Rand, contributed to further concerns, resulting in a significant decline in the number of Taiwanese living in South Africa (Park \& Chen 2009:28).

Park and Chen (2009:28) indicate that the 'third wave of immigration, which overlaps with the second and continues today, is immigration primarily

${ }^{4}$ See also Todes (1998) for an in-depth study of Asian industrialisation in Newcastle. 


\section{Subashini Gordon \& Kathryn Pillay}

from the People's Republic of China'. The number of Chinese from the PRC has grown steadily from the late 1980s but increased towards the period of diplomatic recognition in 1998. Large numbers of legal and illegal migrants have entered South Africa, which has exceeded the total number of South African Born Chinese and Taiwanese and has continued to increase (Park \& Chen 2009:28). Huynh et al. (2010:289) make a further distinction between those migrants from mainland China who have arrived pre-2000 and those who arrived post-2000. Those migrants who arrived in South Africa pre-2000 began arriving in the late 1980s to the period leading up to South Africa's recognition of the PRC in 1998. Most of the migrants were middle managers or professionals. Many of them had links to factories in China located in megacities such as Shanghai or Beijing or the eastern coast of China, 'the majority of them entered into import, retail and wholesale trading as well as manufacturing of consumer products' (Huynh et al. 2010:289). Huynh et al. (2010:289) state that the post-2000 period is marked with a dramatic increase of Chinese migrants coming to South Africa, most of whom comprise small traders and peasants mainly from Fujian province. Kuo (2017) states that new Chinese migrants speak little English and come from poorer towns in China with the hope of becoming successful in South Africa.

Post-2000, including the present day, is characterised by increased bilateral trade policies between China and South Africa which include the Pretoria Declaration on Partnership that was issued in April 2000, a BiNational Commission (BNC) that was established in 2001, a Strategic Partnership which was declared in 2004, and a Programme for Deepening Strategic Partnership which was established in June 2006 (website 1). In addition, in August 2010, former President Jacob Zuma's visit to China culminated in the 'Comprehensive Strategic Partnership' agreement (website 1), and in 2011 South Africa was invited by China to join the Brazil, Russia, India, China (BRIC) group, changing the acronym to BRICS. The BRICS group was formed for emerging economies to cooperate with each other during a changing economic climate (Mhaka \& Jeke 2018). China and South Africa also share multilateral relations - of importance are the 'Forum for ChinaAfrica Cooperation (FOCAC), G20, World Trade Organisation and G77' (Mhaka \& Jeke 2018:5). Bilateral and multilateral agreements strengthen and deepen the economic and political relationship South Africa holds with China. Daniels (2019:1) indicates that 'China is South Africa's biggest trading partner globally, while South Africa is China's biggest trading partner within the 
African continent'. Mohan and Tan-Mullis (2009:589) state that the establishment of FOCAC relations with Africa in 2006, initiated a 'wave of economic migration to Africa by state-influenced construction teams and mining and oil workers, as well as private traders, who are arguably the shapers of development in Africa. And indications are that Chinese are set to increase investment across the continent leading to further migration'. Thus, due to favourable political and economic relations, the migration of Chinese people has accelerated over many parts of the African continent, including South Africa (Mohan \& Tan-Mullis 2009).

The city of Durban has seen a significant increase in independent Chinese migrant traders over the years as South Africa intensifies trade relations with China. 'Chinese shops' have come to line particular streets of the Durban city centre some clustering together in certain districts. The emergence of shopping complexes or 'China Malls' dedicated especially to selling goods imported from China by Chinese migrants has been initiated over the last ten years in Durban. For instance, the China Mall, situated in South Beach, Durban was officially opened on 29 October 2010 as an initiative of the Progressive Business Forum (PBF) SA-China Chapter (website 2). The mall is owned by Robin $\mathrm{Xu}$ who is a member of the $\mathrm{PBF}$ and who also played a significant role in organising trade delegations to China (website 2). In addition, Oriental City was launched early in 2011 and China City opened in the middle of 2011. Kuo (2017) states that 'these buildings have become one of the most visible reminders of China's presence in South Africa, home to the largest Chinese community in Africa'. Although the number of Chinese migrants in these districts have increased and their presence and products have changed the physical structure as well as the cultural milieu of the city of Durban, little is known about their lived experiences. Mohan and Tan-Mullis (2009) indicate that while there is a plethora of information about the macro relationships between China and Africa, there is a lack of qualitative research focusing on Chinese migrants in particular, in different localities. This study therefore aimed to remedy this by focusing on the socio-economic experiences and trajectories of Chinese migrant traders in the city of Durban.

\section{Methodology}

This research was conducted in the city of Durban located in the province of KwaZulu-Natal. Durban is characterised by having a diverse population group, 
which was categorised by law into different 'racial' groups under apartheid. This system of racial segregation which was formally implemented in the 1950s, but was initiated earlier, divided people into 'racial' groups who could only occupy particular areas where they could live and work (Maharaj 1997). The racial categories assigned to people in South Africa, and which continue in contemporary society are 'White', 'Black', 'Coloured' and 'Indian'5. Brookfield and Tatham (1968:64), in their study of the distribution of racial groups in Durban, remarked that:

A unique feature of Durban, not parallel even in Cape Town, is the dual nature of the commercial centre. The larger European Central Business District, with clear division between shopping, commercial, and entertainment areas, overlaps in its poorer, western, end an Indian $\mathrm{CBD}$ in which this a real differentiation of functions is to some extent duplicated. Most European shops, especially in the overlap area depend somewhat on non-European custom, but comparatively few Europeans patronise shops in the Indian CBD. Entertainments are totally separate. This dichotomy is reinforced by the dualism of the transport system. The European bus system, carrying only a few nonEuropeans in segregated seats, focuses on the European center; the privately owned Indian and Native buses, serving the wide Indian and Native areas on the fringes, focus on the Indian commercial core. It should be remarked, however, that the racial separation of business is less clear than it appears to be; Indians own much European land, and Indian money penetrates a substantial sector of the European economy.

As the population of the city grew it became harder for different groups to adhere strictly to the 'racial' zoning (Maharaj 1997). With the abolition of apartheid in the 1990s the city took on a new shape. Although some remnants of a city divided along racial lines still exist, the city has now been transformed into a place where different 'racial' groups are permitted to trade and shop.

5 Prior to the implementation of the new 'racial' categories of 'Black', 'Coloured', 'Indian' and 'White' these groups had the categories of 'Native', 'Coloured', 'Asiatics' or sometimes 'Indian' and 'Europeans' respectively (Brookfield \& Tatham 1968; Kuper, Watts \& Davies 1958). 
South Africa's democratisation has also led to sanctions being discontinued and for a new immigrant population, especially from African countries, to emerge as traders in various parts of the city. This has also been followed by a Chinese population who now live and trade in and around the city centre.

This research was conducted in 'China Malls' that mainly house Chinese businesses. The non-probability purposive sampling method was used in this study. Denscombe (2007:17) states that in purposive sampling the researcher 'deliberately selects particular ones because they are seen as instances that are likely to produce the most valuable data'. During the research participants were purposively chosen based on their ability to speak English. Interviews were held at the Chinese shop owners' premises, as traders were too busy to be interviewed at a neutral location. Interviews were conducted at the China Mall, China City, and the Xin Hua Centre. China Mall, Oriental City and the Xin Hua Centre are located within the confines of the CBD while China City is in the north, less than $15 \mathrm{~km}$ outside the CBD. Observation was also conducted in the places noted above.

The intention of this study was to 'talk interactively with people, to ask them questions, to listen to them and to gain access to their accounts and articulations' which is necessary to gain insights into their lived experience which can only be achieved through qualitative interviewing (Mason 2002:64). Participant observation was also used in this research as a method of producing data which involves 'the researcher immersing herself or himself in a research 'setting' so that they can experience and observe at first hand a range of dimensions in and of that setting' (Mason 2002: 84). In this study, through participation in daily activities of the individuals involved in this study, over a period of five weeks, a deeper understanding of the social environment in which Chinese migrant traders worked, was gleaned.

Semi-structured interviews were used in this research to allow participants to freely engage in topics that were significant to them (HesseBiber \& Leavy 2011:102). The flexibility of this method of data collection, which allows for participants' voices to be heard and provides opportunity to explore uncharted facets, made it an appropriate research instrument for this study. In this research, face-to-face interviews were held with one Chinese migrant trader at a time. Thematic analysis was used to analyse the data from participants which allowed for themes to emerge from the interpretations of the participants' responses. Common experiences were drawn together under these themes (Mason 2002; Denscombe 2007). 


\section{Theoretical Framework}

This research focused particularly on the lived experiences of Chinese migrant traders working in various Chinese malls in Durban, as well as their perceptions of living and working in South Africa. Perceptions and attitudes are constructed based on meanings which are contingent on time and differing social situations. The social construction of these perceptions needs to be contextualised in specific circumstances and must be understood within the broader societal dynamics which shape and influence these realities. Social constructionism therefore is the broad theoretical framework that underpins this study and guides this research. Social constructionism views social reality as being constructed through discourse and social interaction, while emphasising the importance of culture and context in understanding what occurs in society, and constructing knowledge based on this understanding (Burr 1995; Burr 2003).

Since language and meanings implicit within the language used are constructed between people during social interaction they also indicate that people produce their social reality through the language that is used to describe the social world in which s/he lives. Burr (2003:8) indicates that 'when people talk to each other, the world gets constructed'. Thus, our knowledge of the world and our social reality is constructed through the daily interactions of people through the language that they use. By articulating the thoughts and ideas through the words that we use, we create and reproduce our reality which enables us to interact with others. The language that is used in everyday conversation when people interact is seen as important as it also provides a reflection of what is occurring within society.

Berger and Luckmann (1966) indicate that we are born into a society and culture where language, concepts and categories exist, and we internalise these concepts and categories and reproduce them through our actions and when interacting with others. Burr (2003:50) indicates that 'the concepts that we operate with are tied in with the kind of society we live in and are therefore not random'. The people within a society can produce and reproduce concepts and categories that help them to explain and give meaning to the world in which they live. When new knowledge is acquired (through media, and communication with others, for example) people reflect on that knowledge and may come to interpret and form new meanings of the objects in their world and thus they come to react or change their behaviour in accordance with the new information received. However, individuals do not merely internalise these 
concepts and categories, they have the capacity to change, alter, reform or discard concepts or categories (Fay 1996). Ritzer (1996:213) also indicates that 'people need not accept the meanings and symbols that are imposed on them from without' as they have the capacity to oppose and challenge these meanings and interpret and form new meanings of situations.

According to Blumer (1969) interpreting and defining social acts is essential to understanding how individuals react and interact with each-other. Blumer (1969: 66) takes it one step further by stating that 'symbolic interaction involves interpretation, or ascertaining the meaning of the actions or remarks of the other person, and definition, or conveying indications to another person as to how he is to act'. People are not only capable of reflecting and interpreting the world around them but more importantly they are capable of interpreting others' action, interactions and comments towards them. People gain meaning through social interactions and they act according to that perceived meaning.

Burr (1995:4) states that the way in which people come to understand the world also 'depends upon where and when in the world one lives'. Since knowledge is historically and culturally specific this indicates that people live their lives within a certain historical period and with specific cultural beliefs that informs the way they come to understand the world. This study was undertaken within a specific historical and cultural context and cannot be generalised or equated with other societies which are vastly different to the one under study.

The Chinese migrants who have come to South Africa would therefore reflect, interpret and give meaning to their new environment according to the knowledge they received from communicating with other Chinese migrants and by socially interacting with South Africans and other foreigners, especially those from other parts of Africa. This research specifically examines the perceptions of Chinese migrant traders who run businesses in the city of Durban. Thus, it is the Chinese migrants' traders, who are given a 'voice' in this study so that their unique experiences are explicated, recognised and acknowledged.

\section{The Economic and Social Lives of Chinese Migrant Traders in Durban}

The Chinese migrants living and trading in and around the city of Durban, are from various provinces in China. Although the participants in this study have come from different regions within China, their interviews reveal three 
overarching features that they all share which inevitably shape how they conduct their lives within South Africa. The first aspect involves creating monetary wealth by utilizing social networks; the second aspect focuses on how crime, and the fear of crime in South Africa has affected how they live their lives and conduct their businesses; and the third relates to language as a barrier to creating deep and meaningful relationships.

\section{The Use of Social Networks in Creating Wealth and Sustaining Entrepreneurship and Trade}

The liberation of South Africa, and the subsequent reopening of its borders and markets together with the burgeoning trade relations with China, made it easier for Chinese migrants and Chinese products to expeditiously enter the country (Mohan \& Tan-Mullis 2009). However, Chinese people themselves are socialised into a discourse of capitalist wealth creation which facilitates the creation of social networks that enable the increase in businesses and entrepreneurship. Participants indicated that starting a business is an opportunity for them to increase their monetary wealth. The quotes below, are indicative of the views of most of the participants:

Brian: My expectation, I do the business, it's my first business, I can maybe, what do you say, maybe grow up and try to get two or three branches. Then it would be better for the life.

Emily: Grow business, want to own, open ten stores around the world. Lee: Run the business, hope it prospers.

Tracy: I just want more business, nothing else ${ }^{6}$.

The intention of these Chinese migrant traders is to prosper and achieve monetary success in South Africa, and even abroad. When participants were asked what their future goals were, they responded by stating that they would like their business to thrive or prosper and for their business to grow by having more stores. The language participants used indicated that their social reality

${ }^{6}$ The quotations from the participants were transcribed verbatim and included as such in the article. As mentioned earlier on, the participants do not speak fluent English. However, the quotations have been unpacked in the narratives that follow them. 
is thus shaped around an economic discourse of creating and growing their monetary wealth. Their social reality is thus mediated through a capital economic discourse. Examining Chinese history Bian (2002:91) argues that the post-Mao period in the PRC is one where 'state redistributive inequalities are giving way to patterns increasingly generated by how individuals and groups succeed in a growing market-orientated economy'. The death of Chairman Mao in 1976 also saw the collapse of his rigid hierarchical system when Deng Xiaoping implemented market reforms that made it possible for Chinese citizens to have occupational status, occupation and social mobility, denied during Mao's reign, thus leading to a new class system (Bian 2002). Bian (2002) explains that market reforms have led to increased social mobility. For instance, research (spanning two decades) conducted by Lu (cited in Bian 2002:95) on emerging class structures in rural areas within China showed that private entrepreneurs became the new capitalist class. Thus, the social reality of Chinese entrepreneurs is constructed around a discourse of wealth accumulation which influences their behaviour and actions.

Migrants, in this study, reveal that they had different careers in China, however in South Africa, having their own business has come to be a lucrative career. The creation of business and social networks amongst Chinese migrants in South Africa and the importation of cheap goods from China has created the opportunity for migrants to own their own businesses. For instance, participants reveal that they came to South Africa through the recommendation of a friend or family member who came to South Africa before them:

Brian: Before come here, I am come here, it's my brother, he come here first then he go back to China then he go to Canada. He tell me, now the whole country is, how to say it, er improve .... Then come here also find a friend of mine in that shop, he call me and say why not try and open a shop here. Then I come here. I don't know, maybe it's a chance, before I didn't open a shop, a business, just a find people who want anything then I help find it and sell it to them.

Through social networks friends and family can dispense information on business conditions and prospects in South Africa. This information influences the migrant to come to South Africa to trade. Once in South Africa the migrant may use the same social network or may rely on other social networks created to start the business and to find distribution or supply networks. This is evident 
in the case of Brian whose brother informed him of business opportunities in South Africa. His interview revealed further that he was able to manoeuvre his way from Cape Town to Johannesburg as a friend had informed him of opportunities which resulted in him remaining in the country longer than he had originally anticipated. The relatively low cost of goods also allowed him to profit from his business ventures. A friend in Durban thereafter communicated to him that there was an opportunity to open businesses in the city, which resulted in his relocation to the city to explore these new possibilities. It is through these networks that information about business opportunities are dispersed. Brian's relationship with his brother and friends exemplify the gaunxi networks ${ }^{7}$ with information being transmitted from family member to family member or friend to friend. Participants' interaction and action through social networks form the foundation through which trade amongst the Chinese migrants takes place. Social networks are thus created and maintained through the agency of individuals who receive and supply information as to where there are good business opportunities, as well as places in China, Johannesburg and Durban where the cheapest goods can be sourced.

Previous research which focused on Chinese migrant traders in rural areas indicate that the majority of 'Chinese shops' are family owned, and help is usually hired from extended family members who reside in the same village as the migrants in China (Park 2009; and 2012; Park \& Chen 2009; Park \& Huynh 2010). Park and Chen (2009:35) indicate that some male respondents in their study assume the role of apprentices to an uncle, male relative or fellow villager before they can purchase their own business while older relatives that have established businesses may pursue bigger business enterprises in towns or other regions. This suggests that with the help of social networks, Chinese traders are able to establish their own businesses thereby resulting in an increase in 'Chinese shops' in rural areas. Participants' interaction and action through social networks, therefore, form the foundation through which trade amongst the Chinese migrants takes place.

Since their intention is to create wealth, the daily routine of the participants revolves around attending to their businesses during the day and

\footnotetext{
${ }^{7}$ Guanxi networks are 'interpersonal connections of sentiments and obligations that dictate social interaction and facilitate exchange in Chinese society' (Bian 2002:107). According to Bian (2002:108) guanxi contacts are usually relatives and close friends.
} 
to their family only once the business day has ended. Participants indicated that they are always busy with operating and managing their business interests. Most of the participants' shops were opened seven days a week. Some Chinese traders also bring their children to their place of work as they do not have child minders. Since most of their time is dedicated to running the business, they have little or no time for leisure activities. Their limited time is dedicated to individual activities such as playing computer games and watching movies or television. When participants were asked to discuss their social lives in Durban, the following statements which captures their sentiments, reveal significant pressures placed on their time:

June: But you see we don't have any time shopping, we don't have time eating outside restaurant. Everyday working, working, working. (laughs) So we don't have time to spend your money.

Justin: Um, always rushing, everyday rushing.

Lee: So it's kinda busy when you have to be here for work and then go back, take care of the whole house.

Their comments indicate that working in their shops and attending to the everyday functioning of their businesses consumes much of their time which leaves little to no space to pursue social activities. In addition to the time constraints which restricts their social interaction, the fear of crime also impacts negatively on the ability of the Chinese migrant traders to engage in social activities in the city.

\section{Fear of Crime and Xenophobia}

The lives, and subsequently the behaviour of Chinese migrants, are influenced by experiences of crime, or the fear of becoming victims of criminal activity in South Africa. Berger (Berger cited in Wallace \& Wolf 1995:262) argues that people, through their actions and interactions establish a shared reality experienceed as objectively factual and subjectively meaningful. Through participants' actions and the language used to express themselves the fear of being victims of crime is created as a social reality. This social reality influences their actions taken within South Africa. For instance, according to the participants, crime prevents and restricts their activities. Tracy, for instance, revealed the difference between residing in South Africa as opposed to China: 
Tracy: Then you know this place, you know in China, um, after finish work we can go on the street, it's so many shop so many shopping mall, some they open and you, er, 1012 o'clock, some its 24 hours. So we can go whatever we want to go. We eat nice food, we can play outside. Here I can't even go out here.

In China, Tracy enjoyed many after work activities such as shopping, going to restaurants, or even spending time out of her home. In South Africa, however, Tracy is restricted to going to work to make a living and then returning straight home. Her statement reveals both sadness and frustration at her predicament. In addition, June states:

June: You see, before in China I got free time in weekends, with my family and friends, we can shopping, we can eating outside, walk street, other street, but here we can't do like that.

Interviewer: Why not?

June: You know it's dangerous, not only Chinese, the other people, most of the other people are scared to stay outside alone.

June establishes two reasons as to why there are constraints in going out, i.e. her economic activity of running the business to obtain monetary wealth keeps her busy, as indicated earlier, and in addition she mentions in this excerpt immediately above, that she cannot go shopping, eat at restaurants or even walk on the road as she fears for her safety. The fear of crime in South Africa prevents her and many other Chinese migrants from conducting basic social activities alone. Another participant, Brian, also reveals that he too must be cautious while driving. He does not feel safe and must always be aware of his surroundings and be conscious of where he stops his vehicle:

Brian: I hope and think my life would be better than the other city. In Johannesburg it's more dangerous, you can't anytime stop your van, you have to think anywhere, you look around, but here more, feeling is good then in Johannesburg. But in whole South Africa I more like Cape Town.

Brian: Here most of the things is good, but I don't like one thing, is the safe, it's too dangerous. In Johannesburg I was robbed twice. One time they took my car away and second time they broke into my house, 
so I, after that, I don't want to stay in Johannesburg again so I moved to Richards Bay and then come here.

His experience of crime has driven him to come to KwaZulu-Natal where he had to start his life again. Tracy revealed that she also experienced crime in Johannesburg and therefore came to Durban in the hope it would be safer for her. This indicates that the Chinese migrants not only come to KwaZulu-Natal or to the city of Durban to seek untapped consumer markets ${ }^{8}$ they also come to escape the crime that has negatively affected their lives in South Africa. Chen also states that her life is guided by her being cautious about the crime in certain areas. During the interview she emphasised being careful and watchful and trying to be safe by doing 'the right things at the right time' such as not wearing jewellery and by being careful as to how she carries her bag. She also does not go anywhere 'too dangerous' and at night she stays at home. These sentiments are aligned with other participants who have made similar remarks about keeping safe in Durban. Kuo (2017) and Tamfu (2017), in their respective interviews with Chinese migrants, indicate that migrants working in China Malls in Johannesburg are also confined to the mall, and stay indoors to the point that they feel like prisoners.

Tracy also reveals that using public transport is also a dangerous activity. She states further that using public transport 'is not safe for us' indicating that it is not safe for the Chinese migrants in contrast to South Africans. Since she does not have a car she is limited as to where she can go and what she can do. This fear of crime therefore affects most leisure activities and prevents the Chinese migrants from completely integrating into society:

Tracy: You don't have a car you can't go anywhere. For Chinese, other people I know they have.

Interviewer: Which other people?

Tracy: Maybe Indian you can by bus, by taxi. For us it's not easy.

Interviewer: Oh, what do you think will happen if you travel by taxi or bus?

Tracy: I think not safe for us.

${ }^{8}$ Haugen \& Carling (2005) indicate that there is a geographical expansion of 'Chinese shops' or as they term it 'Baibuo shops' due to market saturation. 


\section{Subashini Gordon \& Kathryn Pillay}

Tracy implies that while public transport may be safe for South African citizens, she does not feel that it would be safe for her as a foreigner, given the experiences of other migrant communities in Durban. For instance, violent xenophobic backlash in South Africa against foreign African migrants has been widely reported, however not much is known about everyday xenophobic attitudes and activities that are levelled against Chinese migrants in South Africa.

Tracy related her experiences of xenophobia during the interview:

Interviewer: Is it good or bad, how do people treat you?

Tracy: With me, I'm fine. I'm a good person, not like the other Chinese. Um, they how you say, some Chinese they don't like to talk too much and they don't like black people, especially black people. Interviewer: Why?

Tracy: Black people almost all stealing, even if you are nice to them, they just do that.

Interviewer: So some Chinese they don't like black people.

Tracy: Almost.

Interviewer: Almost all. What about other people, white people, Indian people, coloured people, what about them?

Tracy: Not talk too much .... You can't be friends with them, only some, because, er, South Africa also don't like Chinese.

Interviewer: Why do you think that?

Tracy: I don't know, they, I hear one black guy, he is very bad, he say you Chinese you must all go back China. Now I told him if we all go back China you don't have food to eat even, you will die soon. You see now everything come from China. We must be friendly. Some people they don't understand this. They thinking we come to your country it's like, I don't know how to explain it, they just thinking like that. But because of us come here, now your country is getting nicely and many things. You know China is a very strong country, we have everything so we bring then you people also have everything.

The prevailing racialised discourse is revealed in this extract. Although South Africa is a democratic country, the government still promulgates the discourse of 'race' through policies which categorise people based on their 'race', thus this racialised discourse is also used by wider South Africans, and foreigners 
also come to understand, and label South Africans based on their 'race' (Christopher 2002; Seekings 2008). Tracy, therefore, also uses 'racial' classification in constructing herself in relation to South Africans. She identifies herself as being 'a good person' in relation to other Chinese who find South Africans troublesome, especially 'Black' South Africans. The reason indicated by Tracy as to why Chinese migrants dislike 'Black' people is due to criminality, such as stealing, committed by 'them', where 'Black' people are negatively stereotyped as thieves. Due to this they are likely to distrust people from any other 'race' groups. Tracy states that 'you can't be friends with them' indicating that South Africans cannot be trusted. This racialised discourse has thus come to be part of the social reality of the Chinese migrants and guides their perceptions and influences their interactions with South Africans. What is evident however is that Chinese migrants, in this study, are unable to reflect on the ways in which they benefit from 'Black' consumers, while still stereotyping 'Black' people negatively.

Tracy recounts an altercation she had with a South African male who she constructed as being 'very bad'. This interjection was made when he told her that the 'Chinese must go back to China', meaning that she, as a Chinese person, along with her compatriots are not wanted or welcome in South Africa. Since we acquire our identity from those around us, it can be argued that others are also responsible for contributing to a negative impression of ourselves. Taylor (1994:25) indicates that 'misrecognition shows not just a lack of due respect. It can inflict a grievous wound, saddling its victim with a crippling self-hatred. Due recognition is not just a courtesy we owe people. It is a vital human need'. Since harmful derogatory language is used to describe the Chinese migrants, they may very well acquire a negative self-image and as opposed to participating in society they instead cocoon themselves in a collective identity to protect themselves and to preserve a positive image of themselves. Thus, Tracy felt the need to defend herself and the Chinese position in South Africa by referring to the positive aspects of Chinese presence in the country. Tracy reiterates that 'China' is trying to assist South Africa by bringing affordable products to the country and without their help many South Africans would not be able to afford basic necessities. Tracy goes on to say that both sides need to be friendly to cooperate, and since her perceptions of South Africans are that they are prejudiced towards Chinese, Tracy states 'you can't be friends with them'. Her perceptions that South Africans view the Chinese migrants in a negative way causes her to feel 
animosity towards South Africans. It is therefore a challenge for her to live in a country that she views as prejudiced against Chinese and would rather live a confined lifestyle in order to protect herself from prejudice.

Tracy also indicated that South Africans and Chinese mutually exhibit animosity towards each other. The negativity South Africans exhibited towards Chinese migrants could be attributed to the displeasure felt by South Africans toward foreign business owners (more especially from the African continent and China) who are perceived to be 'stealing' employment opportunities and resources from them, or as has been argued by a number of scholars, they are angered that foreigners are in a better economic position in relation to them (Crush 2000; Vale 2002; Nyar 2001). Alden (2007:85) states that 'many Africans are pointing out the possibility that the influx of Chinese migrants, coupled with the negative impact of employment practices and other acts viewed as discriminatory by local people could spark acts of xenophobia and racism' as seen in Lesotho in 1990. However, in South Africa xenophobia is directed towards African foreigners with rare cases of discrimination against Chinese or Europeans being reported (Nyar 2001).

Nevertheless, participants indicate that it is challenging for them to live in a country that they view as prejudiced towards Chinese migrants, with many participants indicating that the prejudice they experience is also extended to interactions with the South African police and the government. For instance, Tracy indicated that government officials were always in her store inquiring if she had followed the product regulations and if she and her workers had the correct documentation to be in South Africa. This was a point of frustration for the participants who indicated that this occurred on a regular basis. Justin also aired his frustrations with the legal system that he felt did not protect the Chinese businesses from criminals, simply because they are foreign traders. These two incidents reveal that they felt discriminated against by the police and by extension the government:

Tracy: Its checking everything, do you have original passport, are

${ }^{9}$ For example, allegations were made against the Chinese community in South Africa, accusing them of skinning donkeys alive for medicinal purposes which resulted in a proliferation of hate-speech against Chinese migrants (Tamfu, 2017). (See also Huynh and Park (2018) for more studies on 'racial' tensions between Chinese and Africans, across Africa). 
your worker have passport are you selling anything like name brands, like do you have licence to selling whatever, it's too much bother.

In addition, the South African and Chinese media also report incidences of Chinese migrants being murdered and assaulted during robberies which fuels concern amongst migrants as they fear becoming victims of crime (Ngwenya 2007; Kanindo 2007; Enslin-Payne 2007). Since Chinese traders are assumed to possess wealth due to their business enterprises they are seen as soft targets for criminals. Chinese shop owners, therefore, also display caution within their stores. Some of the Chinese owners man the cash register themselves for fear of their workers stealing from them. Most Chinese shops either have a dedicated person to watch out for theft or have surveillance cameras to monitor the behaviour of customers. This contributes to the distrust of customers, and people in general, as they must be more watchful and attentive of people around them.

However, China's commerce ministry's Director General for west Asia and Africa, Yabin Zhou, explains that incidents reported in the press have been exaggerated (Kanindo 2007; Enslin-Payne 2007). Since participants have experienced or have heard of incidents of crime against other Chinese migrants, the discourse of crime has shaped how they view their social reality within South Africa. Since the fear of becoming a victim of crime features in their social reality it plays a role in influencing their behaviour. The Chinese traders observed in this study, keep a low profile, keep to themselves and have rudimentary interactions with their customers and workers. In addition, they travel in groups in a private vehicle to and from work instead of using public transportation; they do not wear expensive clothing or accessories; and have limited interactions with the wider public, and since they distrust their employees, they would rather run the shop by themselves than hire staff to manage their shops.

The fear of crime, and distrust associated with crime, prevents many Chinese migrant traders from having deeper relationships with South Africans, or other foreigners. The fear of crime thus penetrates both their social and work lives, and the discourse of crime and prejudice has shaped their lived experiences in South Africa.

\section{Language as a Social Barrier}

In addition to crime hindering the formation of meaningful relationships, the 
challenge of language also contributes to feelings of isolation amongst the Chinese migrant traders. For instance, although June speaks English, the lingua franca in South Africa, she nevertheless still argues that she cannot fully express herself or communicate on a deeper level with South Africans:

June: Um, like the young people, like another uncle his daughter born in South Africa so she is South African Chinese, so the language is okay, but like her father is lived in South Africa for twenty years but he can understand but for speak, speaking still got some problems. And like, me, only for easy, like talking, er, the weather, like the price it's ok but something else, sometime the video in the car.

Interviewer: The radio.

June: The radio in the car, sometimes it's difficult for me to understand.

The participants in this study acknowledge that the ability to effectively speak English, or a local language such as isiZulu, would assist them to not only understand their customers but to also help in socialising and communicating, and ultimately in forming friendships. Many participants complained about the loneliness experienced and the inability to make friends as their English language ability is limited. Participants indicate that it is a challenge to communicate with people and customers as they do not have adequate knowledge of the local languages spoken. It is thus a challenge for Chinese migrants to understand the culture and society in which they live. It is also difficult to effectively conduct their business if they cannot communicate with their customers. In addition, the language barrier also prevents them from understanding local news. They therefore rely on a Chinese newspaper that focuses on Chinese people living in Africa, and not the actual events of the country itself which restricts their understanding of the society in which they reside.

For Brian, speaking English is deemed an advantage as he can have discussions with clients and is able to form friendships with local people who provide him with information relating to the events and culture of the society. Brian also stresses the importance of language for conducting effective business. He remarks that if the language is learnt then they would be able to communicate with other local traders who are very open to assisting them. Brian also stated that while in Johannesburg he decided to change his name 
from a Chinese name to an 'English' name so that people would find his name easier to remember. It was his way of integrating and adapting into a society that he viewed as not particularly welcoming toward Chinese migrants.

\section{Conclusion}

This study reveals that the Chinese migrant traders' main objective in South Africa is to accumulate wealth through entrepreneurship and trade hence their social and economic activities revolve around trading in order to prosper and build a life for themselves. Chinese migrant traders actively form social networks in order to establish or grow their businesses. Social networks of family and friends enable migrants to receive and dispense information on business conditions and potential prospects. Business networks of distribution, supply and trade networks are also created by migrants who use these networks to obtain goods at the cheapest price in order to make a profit. These networks are created and sustained by the Chinese migrants as they continuously invite other migrants into the network, growing the network and increasing trade and business information.

With attention primarily given to trading, their social activity is limited to individual pursuits (such as watching movies) as opposed to face-to-face activities with other Chinese migrants, South Africans, or other foreign nationals. Their work as shopkeepers and traders seemed not only to dominate their lives in terms of time but has become a key source of identification for them as Chinese migrants, and a marker of difference from South Africans. The lack of socializing due to time constraints is further reinforced by the fear of crime. The fear of becoming victims of crime is so embedded in their minds that it affects how daily activities are carried out. The Chinese migrants avoid social contact with locals, avoid participating in social activities, and they constantly monitor their stores. Therefore, social interaction between migrants, South Africans and foreign African migrants primarily occurs within the 'Chinese shops', which serve as spaces through which they experience wider South African society. It could thus be argued that for Chinese traders their shops act as a window through which they experience the larger cultural and social milieu. Their experiences and knowledge of broader society is therefore limited to the people they meet in these trading zones, and based on this limited interaction, perceptions of South Africans, and the different 'race' groups that inhabit South Africa, are formed. 
In addition, as a result of these limited social interactions, integration by Chinese migrants, in contemporary South African society is slow. Their inability to successfully communicate in English, or any other local language, contributes to this, and they are thus unable to form deep and meaningful relationships with South Africans, or other foreign nationals. Chinese migrants are active agents in the creation of social networks that assist them in establishing businesses, however the social climate of crime and prejudice inhibits their activities and confines their lives to 'China Malls'. The challenges they experience related to crime, distrust, prejudice, and the constant surveillance by police, hamper their business and social activities, and continue to position them as the unenviable 'other' in South African society.

\section{References}

Accone, D. 2006. 'Ghost people': Localising the Chinese Self in an African Context. Asian Studies Review 30: 257 - 272.

https://doi.org/10.1080/10357820600897671

Alden, C. 2007. China in Africa. Cape Town: David Philip.

Berger, P. \& T. Luckmann 1966. The Social Construction of Reality: A Treatise in the Sociology of Knowledge. Allan Lane: The Penguin Press.

Bian, Y. 2002. Chinese Social Stratification and Social Mobility. Annual Review of Sociology 28: 91 - 116.

https://doi.org/10.1146/annurev.soc.28.110601.140823

Blumer, H. 1969. Symbolic Interactionism - Perspectives and Method. Englewood Cliff, New Jersey: Prentice Hall.

Brookfield, H.C. \& M.A. Tatham 1968. The Distribution of Racial Groups in Durban: The Background of Apartheid in a South African City. The Geographical Review XLVII, 1: 44 - 65.

https://doi.org/10.2307/212189

Burr, V. 1995. An Introduction to Social Constructionism. London: Routledge. https://doi.org/10.4324/9780203299968

Burr, V. 2003. Social Constructionism. London: Routledge. https://doi.org/10.4324/9780203694992

Christopher, A.J. 2002. To Define the Indefinable: Population Census and Classification in South Africa. Area 34,4: 401 - 408. https://doi.org/10.1111/1475-4762.00097 
Crush, J. 2000. The Dark Side of Democracy: Migration, Xenophobia and Human Rights in South Africa. International Migration 38,6:103 - 133. https://doi.org/10.1111/1468-2435.00145

Daniels, L. 2019. Three Major Agreements just Signed by China and South Africa. Available at:

https://www.thesouthafrican.com/three-major-agreements-just-signedby-china-and-south-africa/ (Accessed on 05 April 2019.)

Denscombe, M. 2007. The Good Research Guide for Small Scale Social

Research Projects. Berkshire England: Open University Press.

Enslin-Payne, S. 2007. Crime deters Chinese Investment. Sunday Independent 04 November 2007, p. 4.

Fay, B. 1996. Contemporary Philosophy of Social Science: A Multicultural Approach. Oxford: Blackwell.

Geldenhuys, D. 1995. South Africa and the China Question: A Case for Dual Recognition. (East Asia Project (EAP) Working Paper Series. Department of International Relations.) Johannesburg: University of Witwatersrand. Guliwe, T. \& S. Mkhonto 2009. Chinese Investments in South Africa. In Yaw, B.A. \& H. Jauch (eds.): Chinese Investments in Africa: A Labour Perspective. Available at:

http://www.cebri.com.br/midia/documentos/315.pdf

(Accessed on 22 October 2012.).

Haugen, H.O. \& J. Carling 2005. The Surge of Baibuo Business in an African City. Ethnic and Racial Studies 28:4: 639 - 662.

https://doi.org/10.1080/01419870500092597

Hesse-Biber, S. \& P. Leavy 2011. The Practice of Qualitative Research. Thousand Oaks: Sage Publications.

Horrell, M. 1954. A Survey of Race-Relations in South Africa. Johannesburg: South African Institute of Race Relations.

Huynh, T.T. \& Y.J. Park 2018. Reflections on the Role of Race in China Africa Relations. In Alden, C. \& D. Large (eds.): New Directions in Africa-China Studies. London \& New York: Routledge. Available at: https://www.academia.edu/37287906/Reflections on the Role of Race in_China-Africa_Relations

(Accessed 12 April 2019).

Huynh, T.T., J.Y. Park \& Y.A. Chen 2010. Faces of China: New Chinese Migrants in South Africa, 1980's to the Present. African and Asian Studies 9: 286 - 306. 


\section{https://doi.org/10.1163/156921010X515978}

Kuo, L. 2017. Chinese Migrants have Changed the Face of South Africa. Now They're Leaving. Available at:

https://qz.com/africa/940619/chinese-traders-changed-south-africa-nowtheyre-leaving/

(Accessed 05 April 2019.)

Kuper, L., H. Watts \& R. Davies 1958. Durban: A Study in Racial Ecology. London: Jonathan Cape.

https://doi.org/10.7312/kupe90906

Laribee, R. 2008. The China Shop Phenomenon: Trade Supply within the Chinese-Diaspora in Africa. Afrika Spectrum 43,3: 353 - 370.

Maharaj, B. 1997. Apartheid, Urban Segregation, and the Local State: Durban and the Group Areas Act in South Africa. Urban Geography 18,2: 135 154. https://doi.org/10.2747/0272-3638.18.2.135

Mason, J. 2002. Qualitative Researching. London: Sage Publications.

Mhaka, S. \& L. Jeke 2018. An Evaluation of the Trade Relationships between South Africa and China: An Empirical Review 1995-2014. South African Journal of Economic and Management Sciences 21,1: a2106. https://doi.org/10.4102/sajems.v21i1.2106

Mohan, G. \& M. Tan-Mullins 2009. Chinese Migrants in Africa as New Agents of Development? An Analytical Framework. The European Journal of Development Research 21,4: 588 - 605.

https://doi.org/10.1057/ejdr.2009.22

Ngwenya, J. 2007. Crime Decried as Robbery Victim is Laid to Rest at Lake. Star 07 May 2007, p. 2.

Nyar, A. 2001. Xenophobia has no Place Here. Daily News 23 March 2001, p. 6.

Park, Y.J. \& T.T. Huynh 2010. Introduction: Chinese in South Africa. African and Asian Studies 9: 207 - 212.

https://doi.org/10.1163/156921010X515923

Park, Y.J. \& Y.A. Chen 2009. Recent Migrants in Small Towns of PostApartheid South Africa. Revue Europeenne des Migrations Internationales 25,1: 25 - 44. ttps://doi.org/10.4000/remi.4878

Park, Y.J. 2009. Recent Chinese Migrants to South Africa - New Intersections of Race, Class and Ethnicity. In Rahimy T. (ed.): Representation, Expression and Identity: Interdisciplinary Perspectives. Oxford, United Kingdom: Inter-Disciplinary Press. 
Park, Y.J. 2012 Living in Between: The Chinese in South Africa. Migration Policy Institute. Available at:

http://www.migrationinformation.org/Feature/display.cfm?id=875

(Accessed 13 January 2012.)

Ritzer, G. 1996. Modern Sociological Theory. $4^{\text {th }}$ Edition. New York: The McGraw-Hill Companies Inc.

Seekings, J. 2008. The Continuing Salience of Race: Discrimination and Diversity in South Africa. Journal of Contemporary African Studies 26,1: 1 - 25. https://doi.org/10.1080/02589000701782612

Song, A. 1993. The South African Chinese Family. Journal of Family Comparative Studies 24,3: 353 - 365.

https://doi.org/10.3138/jcfs.24.3.353

Tamfu, A. 2017. Chinese Migrants have Come to South Africa to Stay but are Finding Some Locals Unfriendly. Africa-China Reporting.

http://africachinareporting.co.za/2017/11/chinesemigrantssa/

(Accessed 12 April 2019.).

Taylor, C. 1994. The Politics of Recognition. In Gutman, A (ed.): Multiculturialism: Examining the Politics of Recognition. Princeton New Jersey: Princeton University Press.

Todes, A. 1998. Socio-spatial Effects of Economic Restructuring: The Case of Newcastle. Society in Transition 29,1-2: 40 - 57.

https://doi.org/10.1080/10289852.1998.10520144

Vale, P. 2002. Migration, Xenophobia and Security-making in Post-apartheid South Africa. Politikon - South African Journal of Political Studies 29,1:

7 - 29. https://doi.org/10.1080/02589340220149416

Wallace, R.A. \& A. Wolf 1995. Contemporary Sociological Theory. New Jersey: Prentice Hall.

Website 1: http://www.pmg.org.za/report/20100526-department-

international-relations-and-co-operation-political-relatio

(Accessed 12 March 2011.)

https://doi.org/10.1016/S0969-4765(11)70136-9

Website 2 - http://www.chinamall.co.za/mall/mallz/durban.html (Accessed 23 March 2012.)

Wilhelm, J. 2006. The Chinese Communities in South Africa. In Buhlungu, S., J. Daniel, R. Southall \& J. Lutchman (eds.): State of the Nation. South Africa: Human Research Council. 
Subashini Gordon \& Kathryn Pillay

Yap, M. \& D.L Man 1996. Colour, Confusion and Concessions: The History of Chinese in South Africa. Hong Kong: Hong Kong University Press.

Subashini Gordon

$\mathrm{PhD}$ Candidate Sociology

University of KwaZulu-Natal

Durban

subashinigovender23@gmail.com

Kathryn Pillay

Sociology

University of KwaZulu-Natal

Durban

pillaykat@ukzn.ac.za 